\title{
STUDY OF ANTARCTIC ICE SHEET MOTION BY MEANS OF DOPPLER EFFEGT LASER EQUIPMENT
}

\author{
By V. V. Bogorodskiy, I. M. Belousova and I. P. Ivanov
}

(Arkticheskiy i Antarkticheskiy Nauchno-Issledovatel'skiy Institut, Fontanka 34, Leningrad Dio4, U.S.S.R.)

Abstract. Doppler-effect laser equipment was successfully employed in Antarctica in I $969-70$ to measure the rate of ice-sheet motion. The method is based on measuring differential beat frequency generated by the interaction of the direct pulse and its echo. A He-Ne laser with the wavelength of $6328 \AA$ was used in the $15^{\text {th }}$ Soviet Antarctic Expedition. The paper gives detailed results of the measurements along with a description of the equipment used and of the observational procedures. A new modified version of the equipment was made ready for 197 1-72 Antarctic season, and was used in the 18th Soviet Antarctic Expedition in the vicinity of Mirny station. New results are also discussed. Analysis of all available data makes it possible to believe that the movement of the ice sheet is irregular with occasional stops. The progressive motion of the ice sheet is accompanied by strain oscillations.

\section{ELECTROMAGNETIC CHARAGTERISTICS OF SEA ICE IN THE METRE AND DEGIMETRE RANGES, AND ITS RADIO-ECHO SOUNDING}

\author{
By V. V. Bogorodskiy and V. P. Tripolnikov
}

(Arkticheskiy i Antarkticheskiy Nauchno-Issledovatel'skiy Institut, Fontanka 34, Leningrad Dio4, U.S.S.R.)

Abstract. The paper gives measurements of the velocity of electromagnetic wave propagation in sea ice, the tangent loss, and the specific absorption obtained by means of coaxial-line experiments, assuming sea ice to be the dielectric. Measurements have been made at frequencies of $30,60,100,200$ and $400 \mathrm{MHz}$ by pulses of 0.05 and $0.5 \mathrm{~ms}$ and video pulses of $0.02 \mathrm{~ms}$ at a repetition frequency of $10 \mathrm{kHz}$, with temperatures from $-40^{\circ} \mathrm{C}$ to $-10^{\circ} \mathrm{C}$ and salinities $17,8.6,4.4$ and $0.56 \%$. Data obtained on the values of the tangent loss are in a good agreement with those obtained by Addison. The velocity has been found to be constant ( $170 \mathrm{~m} / \mathrm{ms}$ ) for radio and video pulses in the ice at any salinity value and temperatures below $-22^{\circ} \mathrm{C}$. At higher temperatures the velocity decreases being more pronounced with the salinity increase. Data on electrical characteristics of sea ice averaged throughout the ice thickness are presented. These measurements have been made by using long lines, frozen into the ice. Experimental radio-echo soundings of sea ice carried out at the drifting stations SP-I9 and SP-2 I in $1971-72$ and $1972-73$ by means of pulsed radar systems in the range 200- $100 \mathrm{MHz}$ are also discussed. 